\title{
Neutrophil-Lymphocyte ratio and C-Reactive Protein Levels in Acne Vulgaris Patients Treated with Systemic Isotretinoin
}

\author{
Sistemik İsotretinoin Tedavisi Alan Akne Vulgaris Hastalarında Nötrofil- \\ Lenfosit Oranı ve C-Reaktif Protein Düzeyleri
}

\author{
DCahit Yavuz \\ Konya City Hospital, Department of Dermatology, Konya, Turkey
}

\begin{abstract}
Introduction: Inflammatory mediators have importance in acne vulgaris pathogenesis. Which mediators cause lesions or increase with which variants is not clear. Neutrophil-lymphocyte ratio and C-reactive protein are the inflammatory indicators that used for follow up of inflammatory diseases. There are various studies state that neutrophil-lymphocyte ratio and C-reactive protein levels are important for systemic isotretinoin treatment or not. Evaluation of changes in neutrophil-lymphocyte ratio and C-reactive protein levels with systemic isotretinoin treatment is the aim of this study.

Material and Method: Acne vulgaris patients who are treated with systemic isotretinoin and healthy control subjects between January 2006 and December 2016 in Konya Training and Research Hospital Dermatology outpatient clinic are included to study. Neutrophillymphocyte ratio and C-reactive protein levels compared in each group at the beginning of treatment and at the 3rd month.

Results: 50 patients ( 28 of women and 22 of men) who are treated with systemic isotretinoin for acne vulgaris and 50 healthy control patients ( 21 of women and 29 of men) included to study. Mean age of treatment group was 21 (19-23) and control group was 29.5. Neutrophil-lymphocyte ratio are not found statistically significiant in patients and control group at the begining and middle of the treatment (1.84 [3.36-0.51] - 1.62 [4.07-0.68], p:0.107), C-reactive protein levels show a statistically significiant decrease in patient group with treatment $(p<0.028)$.

Conclusion: Systemic isotretinoin treatment may affect neutrophillymphocyte ratio and C-reactive protein levels in patients. Further studies are needed to clarify this relation.
\end{abstract}

Keywords: Acne vulgaris, C-reactive protein, NeutrophilLymphocyte ratio
Öz

Giriş: Akne vulgaris patogenezinde inflamatuar medyatörler önem taşımaktadır. Hangi medyatörlerin hangi değişkenler ile lezyon gelişimine veya artışına sebep olduğu net değildir. Nötrofil lenfosit oranı ve C-reaktif protein kronik hastalıkların takibinde kullanılan inflamatuar belirteçlerdir. Sistemik isotretinoin tedavisi bazı çalışmalarda inflamatuar belirteçler üzerine etkili bulunurken bazı çalışmalarda etkisiz olduğu bildirilmiştir. Bu çalışmanın amacı sistemik isotretinoin tedavisinin C-reaktif protein ve nötrofil/lenfosit oranı üzerine olan etkisinin araştırılmasıdır.

Gereç ve Yöntem: 1 Ocak 2016 ile 31 Aralık 2016 tarihleri arasında Konya Eğitim ve Araştırma Hastanesi Deri ve Zührevi Hastalıklar polikliniğine ayaktan başvuran ve sistemik isotretinoin tedavisi alan 18 yaş üstü akne vulgaris hastalarının kayıtları taranarak tedavi başlangıcı ve tedavinin 3.ayındaki nötrofil lenfosit oranları ve C-reaktif protein düzeyleri karşılaştırılmıştır. Bulunan sonuçlar benzer demografik yapıdaki normal hasta grubuyla karşılaştırılmıştır.

Bulgular: 28 kadın,22 erkek olmak üzere toplam 50 hasta ve 21 kadın, 29 erkek olmak üzere toplam 50 sağlıklı kontrol hastası çalışmaya dahil edildi. Tedavi grubundaki hastaların yaşları 19 ile 23 arasında, kontrol grubu hastalarının yaşları ise 18 ile 35 arasında değişmekteydi. Nötrofil lenfosit oranı başlangıç ve tedavi ortasında hem hasta hemde kontrol grubunda anlamlı bulunmezken (1,84 [3,36-0,51] - 1,62 [4,07$0,68]$, p:0,107), C-reaktif protein düzeyleri hasta grubunda tedavi ile istatistiksel olarak anlamlı azalma göstermiştir $(p<0,028)$.

Sonuç: Sistemik isotretinoin tedavisi nötrofil-lenfosit oranı ve C-reaktif protein düzeyleri üzerinde etkili olabilir. Bu ilişkiyi açılamak için daha geniş kapsamlı çalışmalara ihtiyaç vardır.

Anahtar Kelimeler: Akne vulgaris, C-reaktif protein, Nötrofil-Lenfosit oranı 


\section{INTRODUCTION}

Acne vulgaris is a self-limited, chronic inflammatory disease, which usually affects the pilosebaceous unit in adolescents.

${ }^{[1]}$ It is seen nearly in $80 \%$ of the adolescents and the young adults between the ages of 11-30. ${ }^{[2]}$ Oral isotretinoin (13cis retinoic acid) was approved by US Food and Drug Administration (FDA) in 1982. It is one of the most used drug preferred in dermatology practical from that day to the present. In the past 30 years, there is no more effective treatment for acne vulgaris. It emerges as first choice in treatment for severe and resistant acne vulgaris. Isotretinoin is the only drug that effective for all the factors in acne vulgaris pathogenesis. It's effects are;

1. Decrease in sebum secretion,

2. As a secondary of decrease in sebum secretion, decrease in P.acnes colonisation by disrupting suitable environment for P.acnes colonisation because of shrinkaging of pilosebaceus channels,

3. The prevention of comodegenesis by decreasing hyperkeratinisation,

4. Anti-inflammatory effect by stimulating of monocyte chemotaxis.

Since the introduction of isotretinoin treatment for acne, a variety of laboratory monitoring intervals have been used in clinical practice. ${ }^{[3]}$ Routine monitoring for complete blood count is unwarranted ${ }^{[4]}$ Reports of severe leukopenia and or thrombocytopenia are likely idiosyncratic. ${ }^{[5,6]}$ Lipid abnormalities are the most common laboratory abnormality seen with isotretinoin therapy. ${ }^{[7]}$

The patients must be evaluated carefully at the beginning of systemic isotretinoin treatment;

- Detailed personal medical history must be obtained from patient,

- Is there any familial or personal history for hypertriglyceridemia or related lipid disorders?

- Is there any disorder that can effect liver functions?

- Is there any medication currently for any disorder at beginning?, and

- All female patients in childbearing age must be monitored preferably monthly for pregnancy.

Inflammatory mediators have importance in acne vulgaris pathogenesis. ${ }^{[8]}$ Which mediators cause lesions or increase with which variants is not clear. Neutrophil-lymphocyte ratio and C-reactive protein are the inflammatory indicators which are used for follow up of inflammatory diseases. Systemic isotretinoin treatment found as effective on inflammatory indicators in some studies but it is found ineffective some other studies. The aim of this study is evaluate the effect of isotretinoin treatment on c-reactive protein and neutrophillymphocyte ratio.

\section{MATHERIAL AND METHOD}

\section{Study design}

It's a single center, retrospectively designed study. Local ethic commitee approval was obtained. Medical records of dermatology outpatient clinic patients between January 2016 and December 2016, retrospectively scanned with hospital information management system (HBYS). Acne vulgaris patients who are treated with systemic isotretinoin are included to study. Patients with concomitant systemic disease (diabetes mellitus, goiter etc) and under 18 years of age are excluded. Neutrophil-lymphocyte ratio and C-reactive protein levels of patients recorded at the beginning of treatment and at the $3 \mathrm{rd}$ month of treatment. Records have been compared with healthy patient group which has similar demographic structure.

\section{Statistical analysis}

Categorical variables were expressed as percent (\%). Central tendency is expressed by mean and median, and dispersion by standard deviation and range, interquartil range Normal distribution was ruled out by the Kolmogorov-Smirnov and histogram plots. The differences between groups were assessed using Mann-Whitney $U$ test for independent samples and Wilcoxon Signed Rank test for related samples with non-normal distrubiton. Values of $p<0.05$ were considered statistically significant. The statiscal analysis of study has been done with SPSS Version 15.0 programme. (SPSS Inc., Chicago, Illinois, ABD)

\section{RESULTS}

50 patients (28 (56\%) of women and $22(44 \%)$ of men) and 50 healthy control patients $(21$ (42\%) of women and 29 $(58 \%)$ of men) are included in the study. The median age of treatment group patients is 21 [19-23] and the mean age of control group patients is $29.5 \pm 7$. The isotretinoin doses are between $20 \mathrm{mg} /$ day and $50 \mathrm{mg} /$ day (Table 1). Pretreatment neutrophil-lymphocyte ratio is not significantly different between patient and control groups (1.6 [1.32-2.02] vs 1.84 [1.39-2.46], p:0.134). Neutrophil-lymphocyte ratio difference between the begining and third month of the treatment is not found statistically significant (7.6 [6.6-9.2] vs 1.79 [1.322.1], p:0.172) (Figure 1). C-reactive protein levels showed a statistically significant decrease in patient group between the first and third month of the treatment (3.27 [3.19-7.7] vs 3.27 [3.02-5.84], p: 0.028) (Figure 2).

\begin{tabular}{lcc|}
\hline \multicolumn{3}{l}{ Table 1. Patient and control group characteristics } \\
\hline & Patient Group n:50 & Control Group n:50 \\
\hline Female $\mathrm{n}(\%)$ & $28(56 \%)$ & $21(42 \%)$ \\
Male $\mathrm{n}(\%)$ & $22(44 \%)$ & $29(58 \%)$ \\
Age $\mathrm{n}(\%)$ & $21[19-23]$ & $29.5 \pm 7$ \\
Isotretinoin Dosage & & \\
$20 \mathrm{mg} /$ day & $4(8 \%)$ & - \\
$30 \mathrm{mg} /$ day & $9(18 \%)$ & - \\
$40 \mathrm{mg} /$ day & $31(62 \%)$ & - \\
$50 \mathrm{mg} /$ day & $6(12 \%)$ & - \\
\hline
\end{tabular}




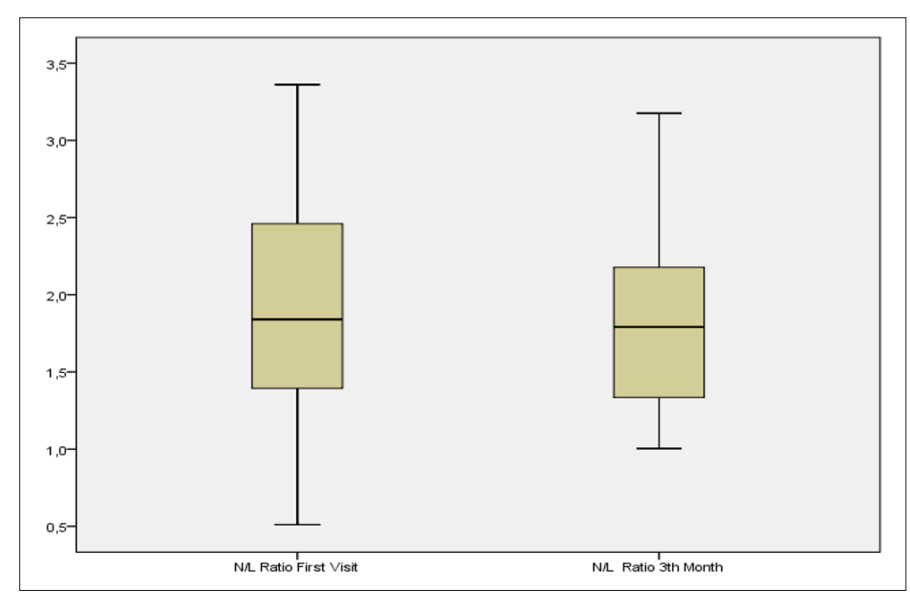

Figure 1. Neutrophil-Lymphocyte ratio, First and 3rd month

\section{DISCUSSION}

We try to evaluate neutrophil-lymphocyte ratio and C-reactive protein levels in acne vulgaris patients who are treated with systemic isotretinoin. We found neutrophil-lymphocyte ratio is not affected with treatment compared with healthy control group at first and third month of treatment. But C-reactive protein levels are significantly decreased between first and third month of treatment in patients. It was compatible for observation that C-reactive protein levels decrease with diminished inflammation.

Acne vulgaris is one of the most treated disorder by dermatologists. It often affects adolescents. Acne vulgaris is a public health problem. It's estimated that nearly $80 \%$ of people affected with acne vulgaris in lifetime. There are many different treatment modalities for acne vulgaris. Systemic isotretinoin is the most effective one in this group. It is effective for all types of acne but it is preferrable for severe or resistant acne vulgaris because of it's advers affects.

C-reactive protein is an acute phase protein which increase with injury, infection and inflammation and decreases with healing or improvement..$^{[9]}$ CRP concentration may increase more than 1000 times in severe inflammatory states. ${ }^{[10]}$ CRP is a multifunctional component of the human innate host defense system. All humans have CRP but it's unknown that all CRP is functional or not. CRP levels increase in inflammation and injury but it's not same as in all humans. ${ }^{[1]]}$ Liver is the main organ for CRP synthesis. Liver synthesizes CRP with the stimulation of cytokine. ${ }^{[12]}$ It's possible to lead elevated CRP levels in acne vulgaris. Disease severity maybe the decisive for CRP levels. Neutrophil-lymphocyte ratio is foreseen that it will be used as inflammatory indicator in recent years.

There are various studies about C-reactive protein levels in acne vulgaris patients and neutrophil-lymphocyte ratio. Ataseven et al. indicate that there is no any important differences in neutrophil count, lymphocyte count and neutrophil-lymphocyte ratio in the patients who get systemic isotretinoin treatment. ${ }^{[13]} \mathrm{Namazi}$ et al. indicate that C-reactive protein levels in severe acne vulgaris patients is not different

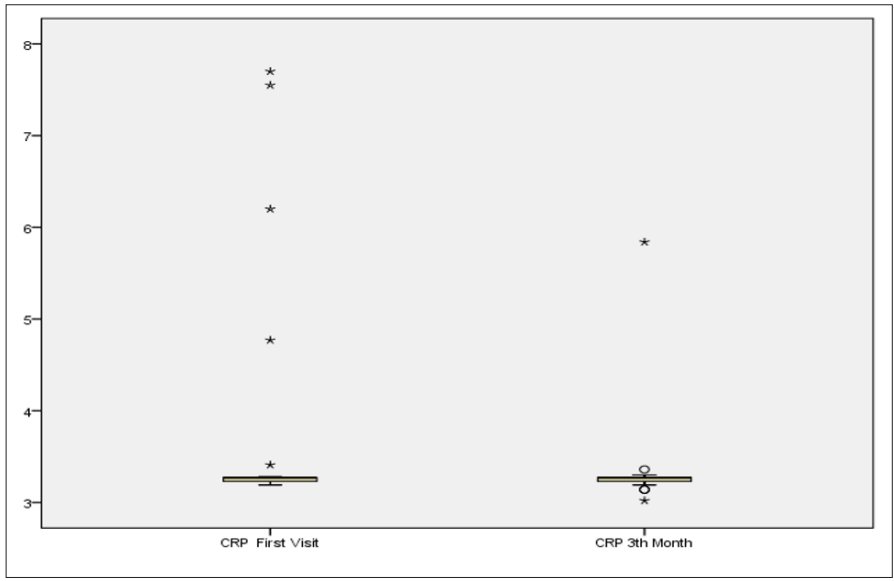

Figure 2. CRP levels, First and 3rd month

from normal population. ${ }^{[14]}$ For psoriasis, Sen et al. indicate that neutrophil-lymphocyte ratio is significantly high in psoriasis vulgaris patients. ${ }^{[15]}$ It is possible to conclude that different disorders have different pathogenetic mechanisms. Inflammatory markers are not the same changes in all situations.

Systemic isotretinoin therapy has multiple effects on acne vulgaris pathogenesis. Anti-inflammatory effect is one of them. Decrease in CRP levels in patients with treatment may be associated with anti-inflammatory effect of isotretinoin therapy. Isotretinoin makes this effect through suppression of mTORC1 and downregulation of inflammatory driving protein, S100a7a. ${ }^{[16,17]}$

Limitations: This was a single-center retrospective study and the results may not be generalizable to other populations. The historical laboratory data was extracted from our hospital management system, not a controlled trial.

\section{CONCLUSION}

It is stated in our study that there is a significant changes only in C-reactive protein levels. CRP or Neutrophil-lymphocyte ratio alone or both can be use for treatment follow up. It is thought that reduction in inflammation with the regression of acne vulgaris lesions can cause decrease in CRP levels. Follow up of C-reactive protein levels in patients who get systemic isotretinoin treatment can be suitable for usage as lab indicator. The questions should be asked are; is there any relationship between the severity of acne lesions and CRP levels and are there any changes in CRP levels with healing level of acne. Further prospective controlled studies are needed to find answers for these questions.

\section{ETHICAL DECLARATIONS}

Ethics Committee Approval: The study was carried out with the permission of Faculty of Medicine Ethics Committee of Selçuk University (Date: 24.10.2018, Decision no: 2018/365). 
Informed Consent: Because the study was designed retrospectively, no written informed consent form was obtained from patients.

Referee Evaluation Process: Externally peer-reviewed.

Conflict of Interest Statement: The authors have no conflicts of interest to declare.

Financial Disclosure: The authors declared that this study has received no financial support.

Author Contributions: All of the authors declare that they have all participated in the design, execution, and analysis of the paper, and that they have approved the final version.

\section{REFERENCES}

1. Brito Mde F, Sant'Anna IP, Galindo JC, Melo Rosendo LHP, Santos JB. Evaluation of clinical adverse effects and laboratory alterations in patients with acne vulgaris treated with oral isotretinoin. An Bras Dermatol. 2010;85:331-7.

2. Polat M, Oztaş $\mathrm{P}$, Ilhan $M N$, Allı N. Clinical side effects and results of systemic isotretinoin treatment in patient with nodulocystic acne. Turkiye Klinikleri J Dermatol. 2008;18:72-6.

3. Lee YH, Schamitz TP, Muscat J, Chen A, Gupta-Elera G, Kirby JS. Laboratory monitoring during isotretinoin therapy for acne; a systematic review and metaanalysis. JAMA Dermatol. 2016;152:35-44.

4. Zane L, Leyden W, Marqueling A, Manos M. A population-based analysis of laboratory abnormalities during isotretinoin therapy for acne vulgaris. Arch Dermatol. 2006;142:1016-1022.

5. Ozdemir M, Kose M, Karakukcu M, Ferahbas A, Patiroglu T, Koklu E. Isotretinoin-induced agranulocytosis. Pediatr Dermatol 2007;24:425-426.

6. Aurousseau M, Levacher S, Beneton C, Blaise M, Pourriat J. Transient dysfibrinogenemia and thrombocytopenia associated with recurrent acute pancreatitis in the course of isotretinoin therapy. Rev Med Interne. 1995; 16:622-625.

7. Barth J, Macdonald-Hull S, Mark J, Jones R, Cunliffe W. Isotretinoin therapy for acne vulgaris: a re-evaluation of the need for measurements of plasma lipids and liver function tests. Br J Dermatol. 1993;129:704-707.

8. Tanghetti EA. The role of inflammation in the pathology of acne. J Clin Aesthet Dermatol 2013; 6: 27-35.

9. Deodhar S. C-reactive protein:the best laboratory indicator available for monitoring disease activity. Cleve Clin J Med 1989;56:126-30.

10. Kushner I. The phenomenon of the acute phase response. Ann NY Acad Sci USA. 1982;389:39-48.

11. Pathak A, Agrawal A. Evolution of $C$ reactive protein. Front. Immunol. 10:943.

12. Jupe D. The acute phase response and laboratory testing. Aust Fam Phys. 1996;25:324-329.

13. Ataseven A, Kurtipek GS, Ozturk P. Neutrophil lymphocyte ratio in patients receiving isotretinoin for acne vulgaris. Med Sci 2014;3:1026-31.

14. Namazi MR, Parhizkar AR, Jowkar F. Serum levels of hypersensitive-Creactive protein in moderate and severe acne. Indian Dermatol Online J 2018; 6: 253-7.

15. Sen BB, Rifaioglu EN, Ekiz O, Inan MU, Sen T, Sen N. Neutrophil to lymphocyte ratio as a measure of systemic inflammation in psoriasis. Cutan Ocul Toxicol 2014; 33: 223-7.

16. De Vita V, Melnik BC. The magnitude of mTORC1 Signalling may predict the response to Isotretinoin treatment in patients with Hidradenitis Suppurativa. Dermatology, 2017;233:399-400.

17. Al-Sudany NK, Mohammed NH, Alrifai SB. Down regulation of S100a7a antimicrobial peptide in acne vulgaris patients after isotretinoin therapy. Dermatol Ther 2019;32:e13136. 